\title{
THE ADAPTATION STUDY OF THE QUESTIONNAIRES OF THE ATTITUDE TOWARDS CALL (A-CALL), THE ATTITUDE TOWARDS CAL (A-CAL), THE ATTITUDE TOWARDS FOREIGN LANGUAGE LEARNING (A-FLL) TO TURKISH LANGUAGE
}

\author{
Cahit ERDEM \\ School of Foreign Languages \\ Afyon Kocatepe University \\ Afyonkarahisar, Turkey \\ Abdullah SAYKILI \\ Open Education Faculty \\ Anadolu University \\ Eskisehir, Turkey \\ Dr. Mehmet KOCYIGIT \\ School of Foreign Languages \\ Afyon Kocatepe University \\ Afyonkarahisar, Turkey
}

\section{ABSTRACT}

This study primarily aims to adapt the Foreign Language Learning (FLL), Computer assisted Learning (CAL) and Computer assisted Language Learning (CALL) scales developed by Vandewaetere and Desmet into Turkish context. The instrument consists of three scales which are the attitude towards CALL questionnaire (A-CALL) (composed of 20 questions), the attitude towards CAL questionnaire (A-CAL) (composed of 9 questions) and the attitude towards FLL questionnaire (A-FLL) (composed of 31 questions) respectively. The participants consisted of $\mathbf{3 7 5}$ university students who volunteered to answer the questions. The participants were students at the foreign language preparatory school of a state university in Turkey. The participants were selected using convenience sampling method. A confirmatory factor analysis (CFA) was carried out on the data. The results were often compared with the original scale. The adapted version of the A-CALL questionnaire indicates a similar goodness of fit with the original one, which is mediocre. CFA results indicate that the adapted version of the A-CAL questionnaire is compatible with the original questionnaire showing a fit from mediocre to good. Again, CFA results of the A-FLL subscales reveal a consistent fit with the original subscale.

Keywords: Computer assisted language learning, computer assisted learning, foreign language learning, attitude, scale adaptation.

\section{INTRODUCTION}

Recent developments in Information and Communication Technologies (ICT) have enabled ICT tools to permeate into every walk of life. Convenient operational factors, such as low costs, increased and faster connectivity options and longer battery lives, have also contributed to the ubiquity of computer technologies in our everyday lives. Due to their multimodal affordances, computer technologies have been widely utilized in educational 
settings for a variety of tasks ranging from office and administrative work to enriching classroom practices.

Since computer technologies have developed to provide more interactive, multi-sensory, and autonomous learning opportunities (Tuncok, 2010), the utilization of computers in second/foreign language (S/FL) learning courses have witnessed a considerable increase over the past two decades (Ayres, 2002; Basoz \& Cubukcu, 2014; Oz, 2015). In addition to the aforementioned affordances, the increased multi-modal social connectivity dimension of these technologies, e.g. social network tools, have been attracting S/FL teachers and researchers to exploit these tools for more effective language learning activities (Saykili \& Genc Kumtepe, 2014). For these reasons, an exponential number of language teachers and learners have been using more and more computer-assisted language learning (CALL) applications throughout their language teaching/learning processes (Vandewaetere \& Desmet, 2009). CALL applications that incorporate a combination of text, image, audio and video are considered ideal for language classrooms (Ayres, 2002); and therefore, they have become an increasingly important part of the language-learning process (Basoz \& Cubukcu, 2014; Tschirner, 2001).

Research suggests that enriching the alternative methodologies of modern foreign language teaching and learning with the help of a variety of educational technologies not only contributes to the quality of education delivered, but also provides the learners means with which to pace and monitor their own learning process (Basoz \& Cubukcu, 2014; Hanson-Smith, 1997). Since technology learning environments provide opportunities for individualized learning, CALL applications enable shy learners to take the time to process information and therefore they feel more comfortable in the relatively anonymous and equalizing environment (Ducate \& Lomicka, 2005). Studious learners, on the other hand, benefit from CALL application through proceeding at their own pace to achieve higher levels (Warschauer, Technological change and the future of CALL, 2004). Therefore, CALL platforms are considered to be convenient to create both independent and collaborative learning environments (Kung, 2002). A number of research studies also highlight emotional and affective benefits related to CALL. CALL applications have the potential to provide authentic materials and tasks along with communicative and interactive activities that help reduce the learning stress and anxiety (Basoz \& Cubukcu, 2014; Tuncok, 2010). The capability of CALL to provide more individualized, student-centered learning in a more stress-free and relaxed atmosphere contributes to learner motivation toward language learning (Ayres, 2002; Genc \& Aydın, 2010; Lee, 2000; Mutlu \& Eroz-Tuga, 2013; Ushida, 2005). Thus, CALL is viewed as a valuable extension to traditional language learning (Basoz \& Cubukcu, 2014; Wu, 2010).

Even though numerous research report positive findings toward CALL, a relatively small number of research point to shortcomings. The shortcomings include increased educational costs (Gips, DiMattia, \& Gips, 2004), lack of technological training (Lai \& Kritsonis, 2006), lack of computer literacy skills both on the part of teachers and learners (Felix, 2004), technical problems such as hardware and software problems (Onsoy, 2004), users' fatigue and loss of concentration (Tuncok, 2010) and learners' lack of the necessary meta-skills for coping with the new learning environments (Felix, 2004).

While most research on CALL addresses the issues surrounding what constitutes the most effective CALL software design, and as well as the issues surrounding how to structure CALL learning tasks to achieve the ideal learning conditions for learners, few research studies take learners into account; namely their interactions with CALL applications, individual differences, and privacy and ethics (Vandewaetere \& Desmet, 2009; Wang \& Heffernan, 2010). Individual differences such as personal attitudes play an important role in how learners view CALL and how they interact with CALL applications (Liaw, Huang, \& Chen, 2007; Vandewaetere \& Desmet, 2009). Several research studies on learner attitudes toward CALL postulate that positive attitudes towards the effectiveness of CALL applications in language learning have the potential to raise learners' behavioral intention of using it (Akbulut, 2008; Basoz \& Cubukcu, 2014; Jahromia \& Salimia, 2013; Liaw, Huang, 
\& Chen, 2007; Oz, 2015; Tuncok, 2010). Research also suggests that learners view CALL as a beneficial extension to traditional language learning, if not a replacement (Ayres, 2002; Basoz \& Cubukcu, 2014). Learners are also reported to perceive CALL as an important and remarkably useful aspect of their studies and relevant to their needs (Ayres, 2002). Akbulut (2008, p.18) concludes that learner perceptions of computers sustaining "independence, learning, collaboration, instrumental benefits, empowerment, comfort and communication" promote positive attitudes toward CALL. Studies show that learner attitudes towards CALL and foreign language learning are, indeed, interrelated (Tuncok, 2010; Vandewaetere \& Desmet, 2009). Positive attitudes toward CALL, as such, help raise learner motivation toward language learning (Merisuo-Storm, 2007; Ushida, 2005; Warschauer, 1996). Therefore, positive learner attitudes towards FLL and CALL will greatly enhance their performance both in language learning, and ICT usage $(\mathrm{Oz}, 2015)$.

Attitude which is among the most significant factors affecting the perception and use of CALL in language learning is a much-researched aspect (Yuan, 2006). Plenty of research focused on attitude towards CALL (Campbell, 1990; Houtz \& Gupta, 2001; Teo, 2006). The reason for this focus is that attitudes towards computer use affect users' behavioral intentions, and in turn, actual computer use (Levine \& Donitsa-Schmidt, 1998). In line with this, Teo (2006) concludes that attitude is the key construct in predicting technology acceptance for future use. Therefore, it can be suggested that when applying computers to language learning, students' attitudes towards CALL can be considered as a key predictor (Zhang, 2011, cited in Afshari, Ghavifekhr, Siraj \& Jing, 2013). In addition, as studies investigating students' attitudes towards CALL provide us with the understanding of the value of computers for students, such studies are of great importance (Talebinezhad \& Abarghoui, 2013).

Attitude is defined as "a psychological tendency that is expressed by evaluating a particular entity with some degree of favor or disfavor" (Eagly \& Chaiken, 1993, p.1). However, it is hard to define computer related attitude with respect to language learning. From this aspect, attitude is defined via subscribing to viewpoint of the tripartite model which is composed of cognitive component which involves beliefs or perceptions about attituderelated objects or situations, affective/ evaluative component which expresses the feelings about the cognitive element and appraisal of these feelings, and behavioral component which gives utterance to the attitude (Vandewaetere \& Desmet, 2009, p.351). Computerassisted tools have been integrated into language teaching and this has given impetus to exploring how language learners would approach these new tools; therefore, it is of importance to assess users' attitudes and reflections (Tuncok, 2010). Responding to this need in the literature, Vandewaetere \& Desmet (2009) developed an instrument based on three-component theory of attitude, which is empirically-based and psychometrically sound, to measure attitudes towards computer assisted learning (CAL), foreign language learning (FLL) and computer assisted language learning (CALL).

A major strength of CALL research putting the emphasis on the learners and their attitudes towards CALL is that learners can be ensured against failure and a more adaptive way of CALL becomes possible (Vandewaetere \& Desmet, 2009). Therefore, through gaining a deeper understanding of learner attitudes toward CALL, we could develop informed policies and practices which could initiate more effective CALL applications for better learning outcomes (Jahromi \& Salimi, 2013; Vandewaetere \& Desmet, 2009). However, relatively little research has been done to examine the relationship between attitudes towards FLL and CALL, especially in the Turkish context $(\mathrm{Oz}, 2015)$. What's more, research focusing on learner attitudes toward CALL in Turkish context primarily target pre-service foreign language teachers. For this reason, it becomes of paramount importance to develop/adopt a series of FLL, CAL and CALL attitude scales in order to better understand FL learner's attitudes, especially lower level learners who fail to make sense of the scales in the target language. Therefore, this study primarily aims to fill the gap in literature by adapting the FLL, CAL and CALL scales developed by Vandewaetere and Desmet (2009) into Turkish context. 


\section{METHODOLOGY}

\section{Participants}

The participants consisted of $\mathbf{3 7 5}$ university students who volunteered to answer the questions. The participants were students at the foreign language preparatory school of a state university in Turkey. The participants were selected using convenience sampling method. In convenience sampling, researchers select participants because they are volunteered and available to be studied (Creswell, 2002, p.167). Of the participants, 128 are male (34.1\%) and 247 are female (65.9\%). The ages of the participants range between 18 and 25 . Of the students, $52(13.9 \%)$ are $18,127(33.9 \%)$ are $19,125(33.3 \%)$ are 20, $40(10.7 \%)$ are $21,13(3.5 \%)$ are $22,10(2.7 \%)$ are $23.3(0.8 \%)$ are 24 and $3(0.8 \%)$ are 25 years old. $82.7 \%$ of the sample $(f=310)$ stated they have a computer and $16.5 \%(f=62)$ stated they don't. Three $(0.8 \%)$ students didn't answer this question. The participants were asked to identify their level of computer proficiency. The levels ranged between too bad and very good. 182 of the participants, nearly half of them $(48.5 \%)$, stated their computer proficiency level is average. Their computer proficiency levels are stated as very bad by six students $(1.6 \%)$, bad by $29(7.7 \%)$, average by $182(48.5 \%)$, good by $126(33.6 \%)$ and very good by $29(7.7 \%)$. And for the last, they were asked to identify their perceived success levels of English ranging from very unsuccessful to very successful. Their perceived their success levels of English are stated as very unsuccessful by 15 students $(4 \%)$, unsuccessful by $89(23.7 \%)$, average by $201(53.6 \%)$, successful by $63(16.8 \%)$ and very successful by four $(1.1 \%)$.

\section{Data Collection Tools}

Developed by Vandewaetere \& Desmet (2009), the instrument consists of three scales which are the attitude towards CALL questionnaire (A-CALL) (composed of 20 questions), the attitude towards CAL questionnaire (A-CAL) (composed of 9 questions) and the attitude towards foreign language learning questionnaire (A-FLL) (composed of 31 questions) respectively. These questionnaires, which were reported to be valid and reliable (Vandewaetere \& Desmet, 2009), are based on the three-component theory of attitude, which are cognitive, affective/evaluative and behavioral components. In the attitude towards CALL Questionnaire (A-CALL), cognitive component includes items related to intelligence and foreign language aptitude. Affective/evaluative component includes three subsets of items which are integrative/instrumental orientation and motivation, teacher influence and specific beliefs about CALL and trust in CALL. Finally, behavior/personality component includes inhibition/exhibition subset. The attitude towards CAL questionnaire (A-CAL) is also based on cognitive, affective/evaluative and behavioral/personality components; yet, no further subset within these components are created. In the attitude towards foreign language learning questionnaire (A-FLL), cognitive component includes items related to intelligence and foreign language aptitude and beliefs or preconceptions about FLL; affective/ evaluative component includes integrative/instrumental orientation and motivation and teacher influence; the behavioral/personality component includes items related to exhibition/inhibition, tolerance of ambiguity or the innate ability to deal with ambiguity in an open way and construct of learning effort (Vandewaetere \& Desmet, 2009).

\section{Procedure}

The original scale was developed by Vandewaetere \& Desmet (2009). In 2013 the authors were asked for a permission for the adaptation of the scale to Turkish language. In 2015 the scales were translated to Turkish by English language instructors $(n=5)$. A back translation was made by another English language instructor. After the translation of the scale to Turkish, the Turkish version was sent to a Turkish language expert (PhD). The returned and controlled version was evaluated by a group of 13 students using the focus group method. In focus group method, a group of individuals is formed by the researcher to hold discussions on group beliefs and group norms on a particular topic (Bloor \& Wood, 
2006, p.88) and it is a means of determining whether ideas that underlie constructs of interest make sense to respondents (DeVellis, 2003, p. 156). The students were asked to evaluate the questions for lucidity and they were asked to mark the questions they did not understand clearly. After this phase, the last version of the scale was directed to $\mathbf{3 7 5}$ university prep school students and a confirmatory factor analysis was carried out on the data. The results were often compared with the original scale of Vandewaetere \& Desmet (2009).

\section{Evaluation of Model Fit}

While evaluating the model fit of the scale, some fit indices were used. The first index of fit used is the ratio of chi-square and degree of freedom ( $\mathrm{X} 2 / \mathrm{df}) . \times 2 / \mathrm{df}<5$ shows an adequate fit, $X 2$ / df $<3$ shows a good fit and $X 2$ / df $<2$ shows a perfect fit (Cokluk, Sekercioglu \& Buyukozturk, 2012). Of the fit indices, GFI and AGFI take values between 0 and 1. 0 indicates no fit, .90 indicates good fit and .95- 1.0 indicates a perfect fit (Cokluk, Sekercioglu \& Buyukozturk, 2012, Joreskog, \& Sorbom, 1982; Smith \& McMillan, 2001; Vandewaetere \& Desmet, 2009). For AGFI, .85 may be taken as the cut-off point as well (Hu \& Bentler, 1999; Vandewaetere \& Desmet, 2009). As for RMSEA, 0 represents a perfect fit while 1 means no fit. RMSEA $<.05$ represents a close fit, RMSEA $<.06-.09$ represents a fair fit, RMSEA < .10 shows a mediocre fit and RMSEA $>10$ shows a poor fit. CFI ranges between 0 and 1.0 means no fit, .90 means adequate fit and .95-1.0 indicates a perfect fit. NFI and NNFI ranges between 0 and $1 . .90$ is a cut off point for good fit and .95 or more indicates a perfect fit (Browne \& Cudeck, 1992; Cokluk, Sekercioglu \& Buyukozturk, 2012; Hu \& Bentler, 1999; Smith \& McMillan, 2001; Vandewaetere \& Desmet, 2009).

\section{RESULTS}

This section includes findings regarding the validity and reliability of the three scales respectively. For construct validity, confirmatory factor analyses were carried out and provided for each scale, and for reliability, Cronbach's alpha and Pearson correlations are calculated and reported for each scale.

\section{A-CALL}

\section{Confirmatory Factor Analysis Results}

The first criteria to evaluate the model fit is $\mathrm{X}^{2}$ / df. If $\mathrm{X}^{2}$ / df is under 5, it means there is an adequate fit of model. As can be seen from the Table 1, $X^{2}$ / df is 3.58, indicating an adequate fit. GFI, AGFI, NFI, NNFI and CFI indices show better fit closer to 1 and a worse fit closer to 0 . As can be seen from the table, GFI and AGFI indicate a perfect fit. CFI, NNFI and NFI indicate a poor fit though. RMSEA smaller than .09 represents a fair fit, which is .083 here. As can be inferred from the values here, there is an acceptable mediocre goodness of fit (see Figure 1). The original version of the scale indicated a mediocre model fit as well (Vandewaetere \& Desmet, 2009, p. 359).

Table 1. A-CALL confirmatory factor analysis goodness of fit indices

\begin{tabular}{ccccccc}
\hline $\mathrm{X}^{2} / \mathrm{df}$ & RMSEA & GFI & AGFI & CFI & NNFI & NFI \\
3.58 & 0.083 & 0.96 & 0.95 & 0.43 & 0.35 & 0.42 \\
\hline
\end{tabular}




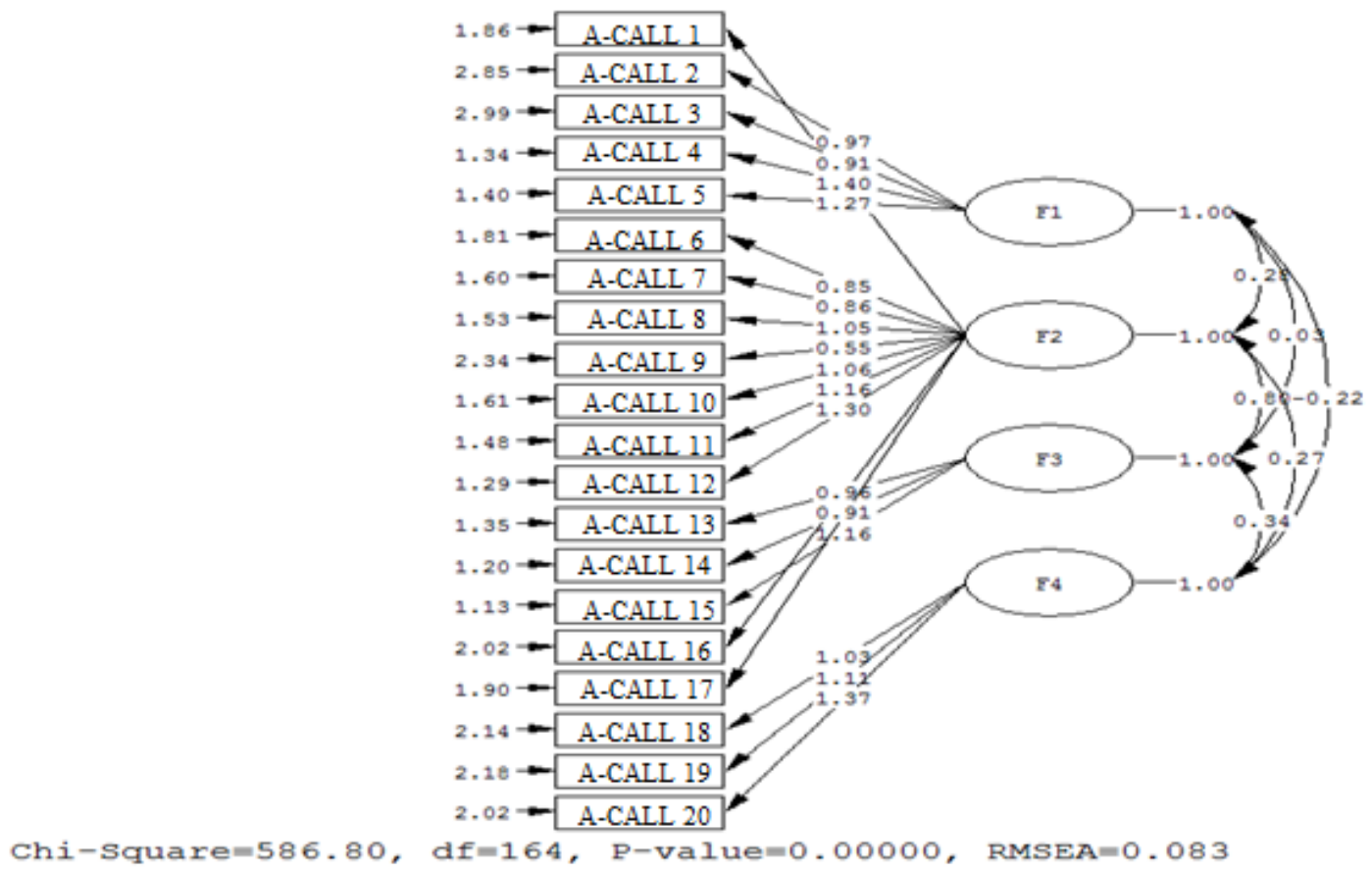

Figure 1. A-CALL Confirmatory factor analysis results

Reliability and Correlations between the Sub-scales of A-CALL

When the A- CALL subscales are analysed (Table 2 ), it can be said that the means $(\bar{x})$ standard deviations (Sd), reliability (a) and Pearson correlation values are in accordance with the original scale (Vandewaetere \& Desmet, 2009, p. 360). Similar to the original version of the scale, reliability values for all the subscales are higher than .60 (a>.60). Furthermore, all the subscales show positive significant correlation except effectiveness of CALL and degree of exhibition to CALL subscales. There is a significant negative correlation between these subscales $(r=-.149, p<.01)$.

Table 2. A-CALL= Means $(\overline{\mathbf{x}})$ Standard Deviations (Sd), reliability (a) and Pearson Correlations between A-CALL subscales

\begin{tabular}{|c|c|c|c|c|c|c|c|c|}
\hline & $\overline{\mathbf{x}}$ & Sd & $\mathbf{a}$ & 1 & 2 & 3 & 4 & Total \\
\hline $\begin{array}{l}\text { 1.Effectiveness } \\
\text { of CALL }\end{array}$ & 15.20 & 5.46 & .711 & 1 & $.182^{* *}$ & .013 & $-.149^{* *}$ & $.417^{* *}$ \\
\hline $\begin{array}{l}\text { 2.Surplus } \\
\text { value of CALL }\end{array}$ & 39.9057 & 10.56 & .842 & $.182^{* *}$ & 1 & $.649^{* *}$ & $.233^{* *}$ & $.778^{* *}$ \\
\hline $\begin{array}{l}\text { 3.Teacher } \\
\text { influence }\end{array}$ & 12.3054 & 4.17 & .790 & .013 & $.649^{* *}$ & 1 & $.277^{* *}$ & $.763^{* *}$ \\
\hline $\begin{array}{l}\text { 4.Degree of } \\
\text { exhibition to } \\
\text { CALL }\end{array}$ & 13.5306 & 4.28 & .642 & $-.149^{* *}$ & $.233^{* *}$ & $.277^{* *}$ & 1 & $.569^{* *}$ \\
\hline
\end{tabular}

A-CAL

Confirmatory Factor Analysis Results

As it is stated before, if $\mathrm{X}^{2} / \mathrm{df}$ is under 5 , it means there is an adequate fit of model. As can be seen from the table $3, \mathrm{X}^{2} / \mathrm{df}$ is 3.17 , indicating an adequate fit. GFI, AGFI, NFI, NNFI and CFI indices show better fit closer to 1 and a worse fit closer to 0 . As can be seen from the table, GFI and AGFI indicate a perfect fit. CFI, NNFI and NFI indicate a good fit though. RMSEA smaller than .09 represents a fair fit, which is .076 here. As can be inferred from the values here, there is a good model fit (see also Figure 2). The original version of the scale indicated similar results as well (Vandewaetere \& Desmet, 2009, p. 362). 
Table 3. A-CAL confirmatory factor analysis goodness of fit indices

\begin{tabular}{lllllll}
\hline$X^{2} / \mathrm{df}$ & RMSEA & GFI & AGFI & CFI & NNFI & NFI \\
3.17 & 0.076 & 0.99 & 0.98 & 0.86 & 0.80 & 0.85 \\
\hline
\end{tabular}

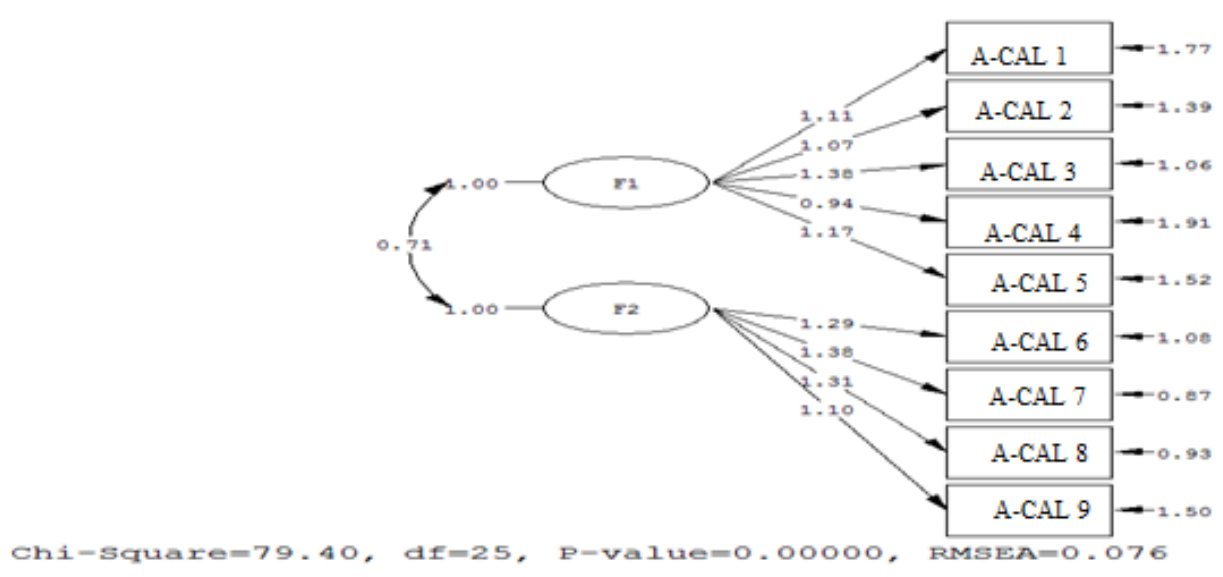

Figure 2. A-CAL Confirmatory Factor Analysis Results

Reliability and Correlations between the Sub-scales of A-CAL

When the subscales of A-CAL are analysed (see Table 4), it can be said that the means $(\bar{x})$ standard deviations (Sd), reliability (a) and Pearson correlation values are in accordance with the original scale (Vandewaetere \& Desmet, 2009, p. 363). Similar to the original version of the scale, reliability values for all the subscales are higher than $.80(a>.80)$. Furthermore, the subscales show positive significant correlation in between $(r=-.573, p<$ $.01)$ and they positively correlate with the total score $(p<.01)$.

Table 4. A-CAL $=$ Means $(\overline{\mathbf{x}})$, Standard Deviations (Sd), reliability (a) and Pearson Correlations between A-CAL subscales

\begin{tabular}{llllrrr}
\hline & $\overline{\mathbf{x}}$ & $\mathrm{Sd}$ & $\mathrm{a}$ & $\begin{array}{c}\text { computer } \\
\text { proficiency }\end{array}$ & $\begin{array}{c}\text { computer } \\
\text { integration }\end{array}$ & $\begin{array}{c}\text { CAL } \\
\text { Total }\end{array}$ \\
\hline $\begin{array}{l}\text { 1.Computer } \\
\text { proficiency }\end{array}$ & $\mathbf{1 9 . 4 2}$ & $\mathbf{6 . 3 8}$ & .815 & 1 & $.573^{* *}$ & $.879^{* *}$ \\
\hline $\begin{array}{l}\text { 2.Computer } \\
\text { integration }\end{array}$ & 20.65 & 5.45 & .845 & $.573^{* *}$ & 1 & $.895^{* *}$ \\
\hline$* *$ Correlation is & & & & & &
\end{tabular}

**. Correlation is significant at the 0.01 level (2-tailed).

\section{A-FLL}

Cognitive Component Confirmatory Factor Analysis

After the analysis, as it can be seen from table 5 and Figure $3, \mathrm{x}^{2} / \mathrm{df}$ appeared to be high, and did not show a fit. The indices suggested a modification between Cognitive 1 and Cognitive 2 items.

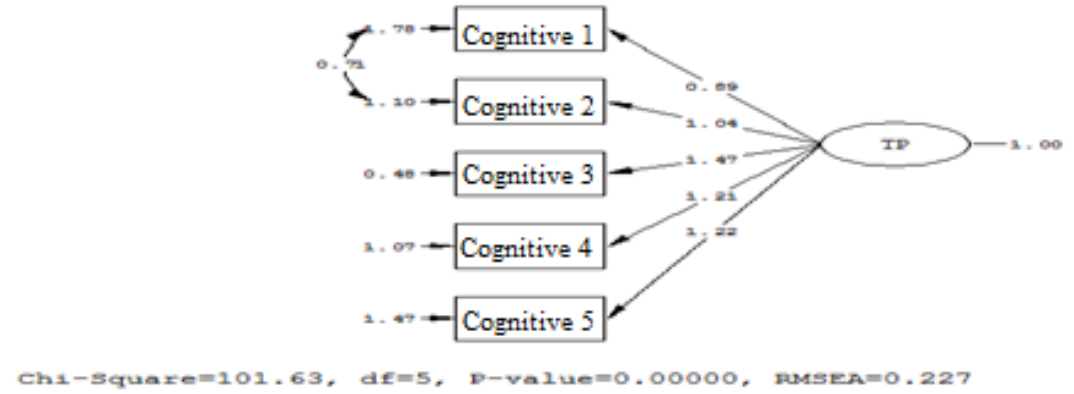

Figure 3. A-FLL Cognitive Component Confirmatory Factor Analysis 
As the meanings of the items were considered to be close with each other and the decrease in the $x 2$ value would be drastic, the modification was carried out. After the modification, the indices were as the following $=(x 213.41(P=0.009))$.

Table 5. A-FLL Cognitive Component Goodness of Fit Indices

\begin{tabular}{lllllll}
\hline$X^{2} /$ df & RMSEA & GFI & AGFI & CFI & NNFI & NFI \\
20.3 & 0.227 & 0.99 & 0.97 & 0.88 & 0.77 & 0.88 \\
\hline
\end{tabular}

As it can be seen from table 6, X2 / df is 3.35, which shows a good fit here. GFI is 1.00 and AGFI, NFI, NNFI and CFI are all higher than .95. These values show a perfect fit. RMSEA shows an acceptable goodness of fit if under .08 , which is .079 here. As can be inferred from the values here, there is a high goodness of fit here, which is consistent with the original version of the scale (Vandewaetere \& Desmet, 2009 pp. 364-365).

Table 6. A-FLL Cognitive Component Goodness of Fit Indices after Modification

\begin{tabular}{lllllll}
\hline$X^{2} / \mathrm{df}$ & RMSEA & GFI & AGFI & CFI & NNFI & NFI \\
3.35 & 0.079 & 1.00 & 0.99 & 0.98 & 0.96 & 0.98 \\
\hline
\end{tabular}

Affective Component subscales confirmatory factor analysis results

If $\mathrm{X} 2$ / df is under 5, it means there is an adequate fit of model. As can be seen from table 7, X2 / df is 2.73, indicating a good fit. GFI, AGFI, NFI, NNFI and CFI indices show better fit closer to 1 and a worse fit closer to 0 . As can be seen from table 7, GFI and AGFI indicate a perfect fit. CFI, NNFI and NFI indicate a mediocre fit though. RMSEA smaller than 09 represents a fair fit, which is $\mathbf{0 6 8}$ here (Figure 4). As can be inferred from the values here, there is a mediocre fit. The original version of the scale indicated good to very good model fit (Vandewaetere \& Desmet, 2009 p. 366).

Table 7. A-FLL Affective Component subscales goodness of fit indices

\begin{tabular}{lllllll}
\hline$X^{2} / \mathrm{df}$ & RMSEA & GFI & AGFI & CFI & NNFI & NFI \\
2.73 & 0.068 & 0.98 & 0.97 & 0.72 & 0.65 & 0.71 \\
\hline
\end{tabular}

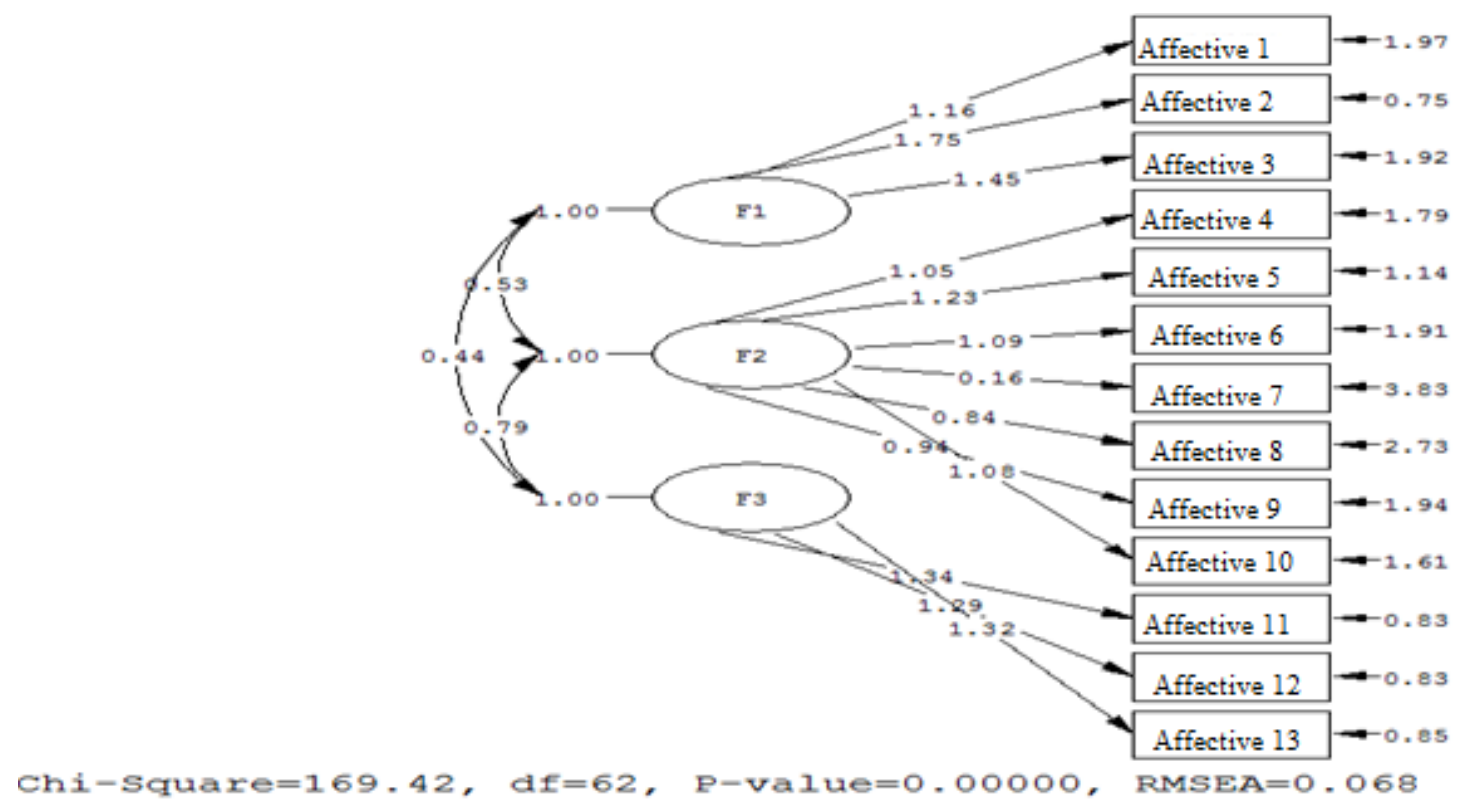

Figure 4. A-FLL Affective Component subscales confirmatory factor analysis results 


\section{Behavioral Component Subscales Confirmatory Factor Analysis Results}

As can be seen from Table 8, $\mathrm{X}^{2}$ / df is 4.03, indicating an adequate fit. GFI and AGFI indicate a perfect fit while CFI, NNFI and NFI indicate a bad fit. RMSEA smaller than .09 represents a fair fit, which is $\mathbf{0 9 0}$ here (Figure 5). As can be inferred from the values here, there is a mediocre fit. The original version of the scale indicated a better fit than this version. (Vandewaetere \& Desmet, 2009, p. 366).

Table 8. A-FLL Behavioral Component subscales goodness of fit indices

\begin{tabular}{lllllll}
\hline$X^{2} / \mathrm{df}$ & RMSEA & GFI & AGFI & CFI & NNFI & NFI \\
4.03 & 0.090 & 0.92 & 0.89 & 0.00 & 2.04 & 1.28 \\
\hline
\end{tabular}

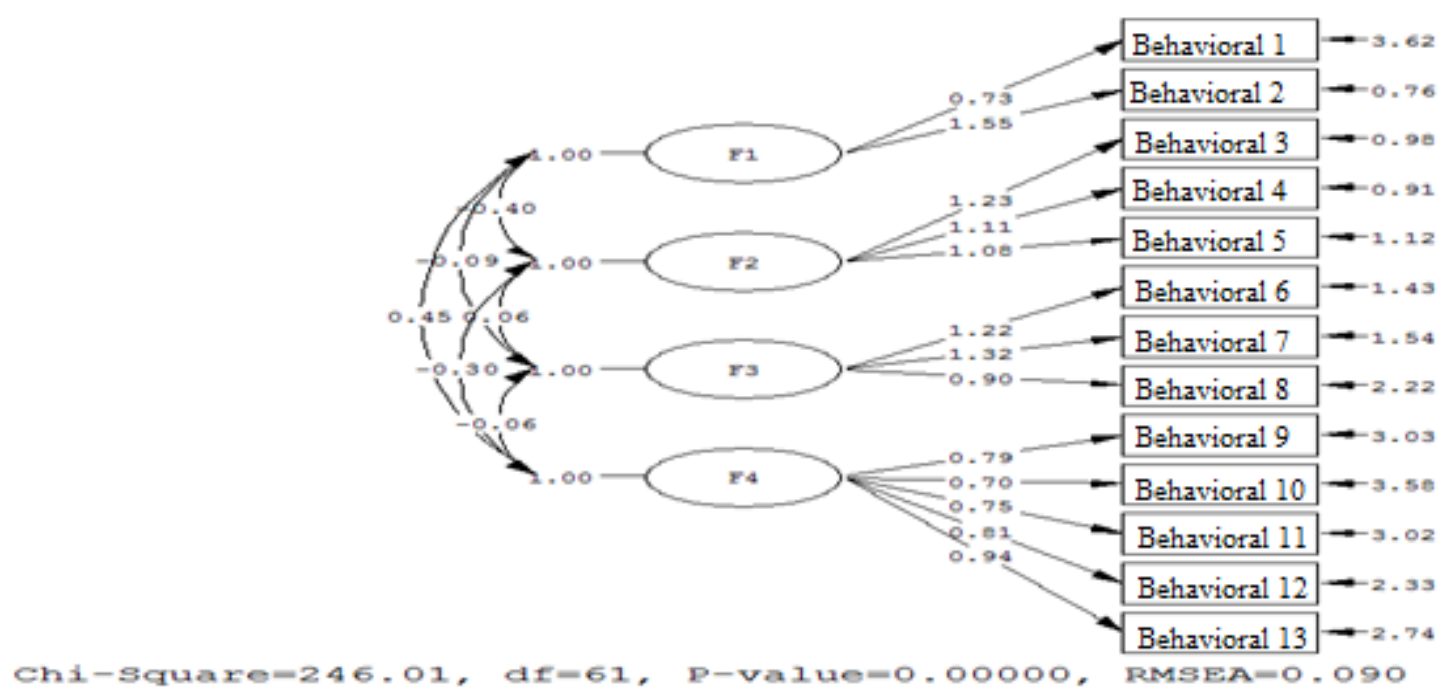

Figure 5. A-FLL Behavioral Component subscales confirmatory factor analysis results

Reliability and Correlations between the sub-scales of A-FLL

When the all components of A-FLL are analyzed (see Table 9), it can be said that the means $(\bar{x})$ standard deviations (Sd), reliability (a) and Pearson correlation values are in accordance with the original scale (Vandewaetere \& Desmet, 2009). Similar to the original version of the scale, inhibition and exhibition components showed negative significant correlation $(r=-.262, p<.01)$. Unlike the original version, there was a negative significant correlation between the components of exhibition and learning effort $(r=-137, p<.01)$ and tolerance and learning effort $(r=-.107, p<.05)$. In the original version of the scale learning effort showed insignificant positive correlation with exhibition $(r=.01, p>.05)$ and significant positive correlation with tolerance of ambiguity $(r=.22, p<.05)$. This difference may derive from the translation, or it can be speculated that tolerance and exhibition items seemed to include less effort in them as the learner can already tolerate the ambiguity and exhibit the target language relatively easily. In other words, these two components could still be true after learning the target language while the effort to learn the language is mostly necessary while learning it. 
Table 9. A-FLL all components Means $(\overline{\mathbf{x}})$ Standard Deviations (Sd), reliability (a) and Pearson Correlations for the cognitive, affective and behavioral subscales.

\begin{tabular}{|c|c|c|c|c|c|c|c|c|c|c|}
\hline 1.Cognitive & $\begin{array}{l}\bar{x} \\
18.45\end{array}$ & $\begin{array}{l}\text { Sd } \\
6.44\end{array}$ & $\begin{array}{l}a \\
.86\end{array}$ & 2.a & 2.b & 2.c & 3.a & 3.b & 3.c & 3.d \\
\hline $\begin{array}{l}\text { 2.Affective } \\
\text { a Extrinsic }\end{array}$ & 15.91 & 4.85 & .79 & 1 & $.297^{* *}$ & $.319^{* *}$ & & & & \\
\hline b Intrinsic & 35.72 & 7.54 & .73 & $.297^{* *}$ & 1 & $.587^{* *}$ & & & & \\
\hline $\begin{array}{ll}\text { c } & \begin{array}{l}\text { Teacher } \\
\text { Influence }\end{array}\end{array}$ & 17.03 & 4.17 & .84 & $.319^{* *}$ & $.587^{* *}$ & 1 & & & & \\
\hline $\begin{array}{l}\text { 3. Behavioral } \\
\text { a Inhibition }\end{array}$ & 7.62 & 3.11 & .48 & & & & 1 & $-.262^{* *}$ & $.136^{* *}$ & $.311^{* *}$ \\
\hline b Exhibition & 16.77 & 3.80 & .78 & & & & $-.262^{* *}$ & 1 & $.205^{* *}$ & $-.137^{* *}$ \\
\hline c Tolerance & 11.63 & 4.14 & .69 & & & & $.136^{* *}$ & $.205^{* *}$ & 1 & $-.107 *$ \\
\hline $\begin{array}{l}\text { d Learning } \\
\text { effort }\end{array}$ & 18.17 & 5.54 & .52 & & & & $.311^{* *}$ & $-.137^{* *}$ & $-.107^{*}$ & 1 \\
\hline
\end{tabular}

$* * \mathrm{p}<.01$ (2-tailed).

$* \mathbf{p}<.05$ (2-tailed).

When the Pearson correlation between all the subscales are examined, it is seen in Table 10 that all the subscales have significant correlations with each other, except the correlations between the subscales of behavioral- inhibition and affective- teacher influence, behavioral- inhibition and affective- total, and behavioral- learning effort and affective- total. Behavioral inhibition subscale has negative correlation with the subscales of behavioral exhibition, affective-intrinsic motivation, affective-teacher influence and affective total. Behavioral learning effort subscale similarly has negative correlations with the subscales of behavioral- exhibition, behavioral- tolerance, affective-intrinsic and affective- teacher influence.

Table 10. A-FLL all components Pearson correlations between subscales

\begin{tabular}{|c|c|c|c|c|c|c|c|c|c|c|}
\hline & 1 & 2 & 3 & 4 & 5 & 6 & 7 & 8 & 9 & 10 \\
\hline $\begin{array}{l}1 \text { behavioral- } \\
\text { inhibition }\end{array}$ & 1 & & & & & & & & & \\
\hline $\begin{array}{l}2 \text { behavioral- } \\
\text { exhibition }\end{array}$ & $-.262^{* *}$ & 1 & & & & & & & & \\
\hline $\begin{array}{l}3 \text { behavioral- } \\
\text { tolerance }\end{array}$ & $.136^{* *}$ & $.205^{* *}$ & 1 & & & & & & & \\
\hline $\begin{array}{l}4 \text { behavioral- } \\
\text { learning effort }\end{array}$ & $.311^{* *}$ & $-.137^{* *}$ & $-.107^{*}$ & 1 & & & & & & \\
\hline 5 behavioral-total & $.629^{* *}$ & $.356^{* *}$ & $.621^{* *}$ & $.455^{* *}$ & 1 & & & & & \\
\hline $\begin{array}{l}6 \text { cognitive } \\
\text { component }\end{array}$ & $.169^{* *}$ & $.230^{* *}$ & $.487^{* *}$ & .032 & $.453^{* *}$ & 1 & & & & \\
\hline $\begin{array}{l}7 \text { affective-extrinsic } \\
\text { motivation }\end{array}$ & $.155^{* *}$ & $.356^{* *}$ & $.163^{* *}$ & $.192^{* *}$ & $.405^{* *}$ & $.193^{* *}$ & 1 & & & \\
\hline $\begin{array}{l}8 \text { affective-intrinsic } \\
\text { motivation }\end{array}$ & $-.171^{* *}$ & $.501^{* *}$ & $.276^{* *}$ & $.248^{* *}$ & $.170^{* *}$ & $.281^{* *}$ & $.297^{* *}$ & 1 & & \\
\hline $\begin{array}{l}9 \text { affective-teacher } \\
\text { influence }\end{array}$ & -.100 & $.558^{* *}$ & $.184^{* *}$ & $-.126^{*}$ & $.239^{* *}$ & $.206^{* *}$ & $.319^{* *}$ & $.587^{* *}$ & 1 & \\
\hline 10 affective-total & -.023 & $.600^{* *}$ & $.259^{* *}$ & -.042 & $.372^{* *}$ & $.286^{* *}$ & $.755^{* *}$ & $.753^{* *}$ & $.805^{* *}$ & 1 \\
\hline
\end{tabular}

\section{DISCUSSION AND CONCLUSION}

For better application of CALL, individual differences such as personal attitudes should be taken into account as they play a significant role in learners' interaction with CALL applications (Liaw, Huang, \& Chen, 2007; Vandewaetere \& Desmet, 2009). It is put forth by numerous studies that positive attitudes towards CALL applications potentially raise learners' behavioral intention of using it (Akbulut, 2008; Basoz \& Cubukcu, 2014; Jahromia \& Salimia, 2013; Liaw, Huang, \& Chen, 2007; 0z, 2015; Tuncok, 2010). Therefore, learner attitudes towards CALL and its related dimensions should be measured to develop informed policies and practices for better learning outcomes (Jahromi \& Salimi, 2013; Vandewaetere 
\& Desmet 2009). To this end, Vandewaetere \& Desmet (2009) developed an instrument consisting of three scales, which are the attitude towards CALL questionnaire (A-CALL), the attitude towards CAL questionnaire (A-CAL) and the attitude towards foreign language learning questionnaire (A-FLL). However, it was not possible to administer these questionnaires to low level language learners as they would not make sense of them. Therefore, this study aimed at adapting the FLL, CAL and CALL scales developed by Vandewaetere and Desmet (2009) into Turkish context.

For the adaptation of the questionnaires, confirmatory factor analysis and reliability analysis of the questionnaires were carried out and reported to put forth the validity and reliability of the translated versions of the questionnaires after the stages of permission, translation, back translation, language check, focus group discussion and application of the questionnaires to students. Analysis of the questionnaires are discussed in this part respectively.

In the original A-CALL scale, goodness-of-fit indices do not indicate a reasonable or good fit. Results of CFA (full sample) include indices as $\mathrm{X} 2=424.24, \mathrm{df}=161, \mathrm{X} 2 / \mathrm{df}=2.64$, RMSEA $=.083$, GFI $=.84$, AGFI $=.79$, CFI $=.89$ and NNFI = .87. RMSEA, GFI, AGFI, CFI and NNFI values indicate a mediocre model fit. The adapted version of the questionnaire indicates a similar goodness of fit, which is mediocre. $\mathrm{X}^{2} / \mathrm{df}=3.58$ indicates an adequate fit. Though GFI (.96) and AGFI (.95) indicate a perfect fit, CFI (.43), NNFI (.35) and NFI (.42) indicate a poor fit. RMSEA (.083) indicates a fair fit. CFA results indicate that the adapted version of the questionnaire is compatible with the original questionnaire. The means $(\overline{\mathbf{x}})$, standard deviations (Sd), reliability (a) and Pearson correlation values of the adapted version comply with the original questionnaire. Cronbach's a coefficients of the subscales are $.80, .86, .91$ and .74 respectively, which are $.71, .84, .79$ and .64 in the adapted version. Reliability values for all the subscales are higher than .60. In addition, $\mathrm{Oz}$ (2015) used this subscale (English version) in Turkish context and found the Cronbach's a coefficient as .83 for the entire scale, ranging between .69 and .89 for the subscales. As to intercorrelations, all the subscales in the adapted version showed positive significant correlation except effectiveness of CALL vs. non-CALL and degree of exhibition to CALL subscales. There is a significant negative correlation between these subscales $(r=-.149, p<$ .01). This case is also similar in the original scale. Like the original scale, the adapted scale is logically consistent and it is a feasible working instrument.

The values of indices of CFA of the original A-CAL questionnaire include (full sample) $\times 2=$ 94.98, $\mathrm{df}=24, \mathrm{X} 2 / \mathrm{df}=3,54, \mathrm{RMSEA}=.103, \mathrm{GFI}=.93, \mathrm{AGFI}=.87, \mathrm{CFI}=.96$ and $\mathrm{NNFI}=.94$. GFI, AGFI, CFI and NNFI values indicate a mediocre to good model fit. These index values for the adapted version of the questionnaire is similar to the original one. In the adapted version, $\mathrm{X} 2$ / df is 3.17, which indicates an adequate fit of model. While GFI and AGFI indicate a perfect fit, CFI, NNFI and NFI indicate a good fit. CFA results indicate that the adapted version of the questionnaire is compatible with the original questionnaire. The adapted version also complies with the original version in terms of reliability. Cronbach's a coefficients of the subscales of the original scale are .92 (computer proficiency) and .80 (computer integration), which is .82 and .85 respectively in the adapted version. Reliability values for all the subscales of both versions are higher than $.80(a>.80)$ and both are internally consistent. As to intercorrelation, the two subscales are positively correlated to each other in the adapted version, which is the same for the original version ( $r=.59$ in the original version, $r=.57$ in the adapted version). The correlation between the subscales and the total score is significantly positive in both versions. These values indicate that the adapted version is compatible with the original scale in terms of model fit, reliability and intercorrelations.

A-FLL questionnaire consists of three subscales as the construct of attitude was split into three subcomponents which are cognitive, affective-evaluative and behavioral. Confirmatory factor analysis results of these subscales reveal a consistent fit with the original subscale. CFA results include $X^{2}=11.32, \mathrm{df}=4, \mathrm{X}^{2} / \mathrm{df}=2.83, \mathrm{RMSEA}=.124, \mathrm{GFI}=$ $.96, \mathrm{AGFI}=.87, \mathrm{CFI}=.99$ and $\mathrm{NNFI}=.97$ for cognitive component; $\mathrm{X}^{2}=71.07, \mathrm{df}=61, \mathrm{X}^{2}$ / 
$\mathrm{df}=1.17, \mathrm{RMSEA}=.037, \mathrm{GFI}=.92, \mathrm{AGFI}=.88, \mathrm{CFI}=.99$ and NNFI $=.98$ for affectiveevaluative component; $X^{2}=97.72, \mathrm{df}=59, \mathrm{X}^{2} / \mathrm{df}=1.66$, $\mathrm{RMSEA}=.074, \mathrm{GFI}=.88, \mathrm{AGFI}=$ .82 , CFI $=.92$ and NNFI $=.90$ for behavioral component. The results for adapted version include $\mathrm{X} 2 / \mathrm{df}=3,35, \mathrm{RMSEA}=.079, \mathrm{GFI}=1.00, \mathrm{AGFI}=.99, \mathrm{CFI}=.98$ and NNFI $=.96$ for cognitive component; $\mathrm{X} 2 / \mathrm{df}=2,73, \mathrm{RMSEA}=.068, \mathrm{GFI}=.98, \mathrm{AGFI}=.97, \mathrm{CFI}=.72$ and NNFI = .65 for affective/evaluative component; $X 2 / \mathrm{df}=4,03, \mathrm{RMSEA}=.090, \mathrm{GFI}=.92$, AGFI $=.89$, CFI $=.00$ and NNFI $=2.04$ for behavioral component. Cognitive component fits to the original questionnaire while affective/evaluative and behavioral components of the original questionnaire indicated slightly better fit than the adapted version. Besides, there is a good fit between the adapted and original versions of the scale with respect to standard deviations, reliability and Pearson correlation values. For instance, inhibition and exhibition components have a negative significant correlation $(r=-.262, p<.01)$ in both versions; however, there is a negative significant correlation between the components of exhibition and learning effort $(r=-137, p<.01)$ and tolerance and learning effort $(r=-.107, p<.05)$ in the adapted version, which differs from the original version. This may be due to translation or it is likely that language learner can already tolerate the ambiguity and exhibit the target language relatively easily.

The questionnaires adapted in this study aimed at providing a standard procedure for constructing and validating measurement for attitude towards CALL, CAL and FLL (Vandewaetere \& Desmet, 2009). The adapted versions of the scales are in high accordance with the original versions as explained above. Besides, this study meets some of the limitations and suggestions provided in Vandewaetere \& Desmet's (2009) study. They suggested further research with more diverse learners of a foreign language. In addition, they stated that the sample size in their study $(\mathrm{N}=240)$ is relatively small. In this study, 375 language learners took the questionnaires, which is an ideal number for performing confirmatory factor analysis. This Turkish adaptation of the study is expected to fill an important gap in the literature as this scales are needed particularly for lower level language learners who cannot make sense of the scales in the target language. The data obtained from these scales would pave for a more effective computer assisted language learning. Further studies with participants of various language learning backgrounds would contribute to the validity and reliability test of the adapted scales.

\section{BIODATA and CONTACT ADDRESSES of AUTHORS}

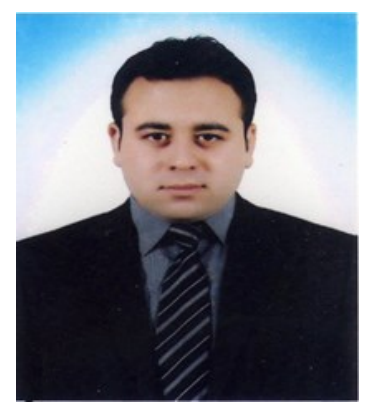

Cahit ERDEM received his BA in English Language Teaching department at Bogazici University, Turkey (2009). He is a PhD student at writing-up stage in curriculum and instruction department at Anadolu University, Turkey. He is currently a lecturer at School of Foreign Languages, Afyon Kocatepe University, Turkey. He has been teaching English at tertiary level for nine years. He has published several articles on media literacy, educational research trends, foreign language teaching and technology, refugee students, and internationalization of higher education. His academic interests include media literacy, curriculum development, teacher education, educational technology and internationalization of higher education.

Cahit ERDEM

School of Foreign Languages

Afyon Kocatepe University, 03200, Afyonkarahisar, Turkey

Phone: +90 2722281397

E-mail: cerdem@aku.edu.tr, cahiterdem@gmail.com 


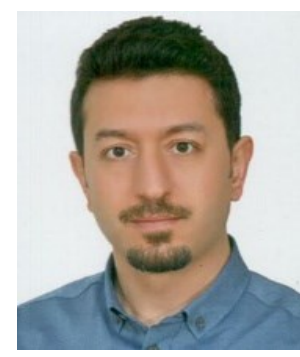

Abdullah SAYKILI received his BA in English Language Teaching and MA in Distance Education. He's currently pursuing his PhD in Distance Education at Anadolu University, Turkey. He worked as an English language instructor in secondary and tertiary levels for thirteen years. He is currently a faculty member at the department of Learning Technologies Research and Development at Open Education Faculty, Anadolu University. His research interests include open and distance learning, multiculturality, culture in online environments, social media and learning, and foreign language learning and teaching.

\section{Abdullah SAYKILI \\ Open Education Faculty \\ Anadolu University, Eskisehir, Turkey \\ Phone: +90 2223350580 / 5643 \\ E-mail: asaykili@anadolu.edu.tr}

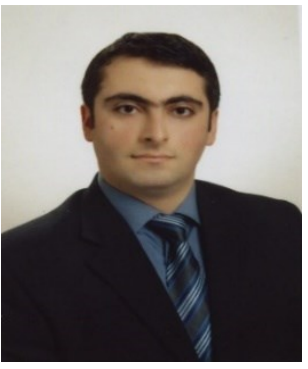

Mehmet KOCYIGIT is a graduate of Selcuk University ELT department (2008) and has taught English for nearly 10 years at tertiary level. Currently, he works at School of Foreign Languages, Afyon Kocatepe University, Turkey. He had his Master's Degree on Educational Sciences at Afyon Kocatepe University, Turkey (2011) and PhD on Educational Administration, Supervision, Planning and Economy at Eskisehir Osmangazi University, Turkey (2017). His research interests include foreign language teaching and technology, teaching young adults, educational administration, leadership, organization, causal attributions and scale development and adaptation.

Dr. Mehmet KOCYIGIT

School of Foreign Languages

Afyon Kocatepe University, 03200, Afyonkarahisar, Turkey

Phone: +902722281397

E-mail: mkocyigit@aku.edu.tr

\section{REFERENCES}

Afshari, M., Ghavifekr, S., Siraj, S. \& Jing, D. (2013). Students' attitudes towards computer-assisted language learning. Procedia Social and Behavioral Sciences, 103, 852-859.

Akbulut, Y. (2008). Exploration of the attitudes of freshman foreign language students toward using computers at a Turkish state university. Turkish Online Journal of Educational Technology, $ᄌ(1), 18-31$.

Ayres, R. (2002). Learner attitudes towards the use of CALL. Computer Assisted Language Learning, 15(3), 241-249. Doi:10.1076/call.15.3.241.8189

Basoz, T., \& Cubukcu, F. (2014). Pre-service EFL teachers' attitudes towards Computer Assisted Language Learning (CALL). Procedia - Social and Behavioral Sciences, 116, 531-535. Doi: 10.1016/j.sbspro.2014.01.253

Bloor, M. \& Wood, F. (2006). Keywords in qualitative methods; a vocabulary of research concepts. Thousand Oaks: Sage Publications.

Browne, M. W., Cudeck, R. (1992). Alternative ways of assessing model fit. Sociological Methods \& Research, 21 (2) 230-258.

Campbell, N. J. (1990). High school students' computer attitudes and attributions: Gender and ethnic differences. Journal of Adolescent Research, 5, 485-499.

Creswell, J. W. (2002). Educational research: planning, conducting, and evaluating quantitative and qualitative. New Jersey: Pearson Education. 
Cokluk, O., Sekercioglu, G. \& Buyukozturk, S. (2012). Sosyal bilimler icin cok degiskenli istatistik SPSS ve LISREL uygulamalari. (2. Ed.) [Multivariate statistics for social sicences= SPSS and Lisrel applications]. Ankara: Pegem Akademi.

DeVellis, R.F. (2003). Scale development: theory and applications. Thousand Oaks: Sage Publications.

Ducate, L., \& Lomicka, L. (2005). Exploring the blogosphere: Use of web logs in the foreign language classroom. Foreign Language Annals, 38(3), 410-421. Doi:10.1111/j.1944-9720.2005.tb02227.x

Eagly, A. H. \& Chaiken, S. (1993). The psychological attitudes. Fort Worth, TX: Harcourt, Brace, Jovanovich.

Felix, U. (2004). A multivariate analysis of secondary students' experience of web-based language learning. ReCALL, 16(1), 237-249. Doi:10.1017/S0958344004001715

Genc, G., \& Aydın, S. (2010). Student motivation towards computer use in EFL learning. IETC (1367-1369). Istanbul = IETC.

Gips, A., DiMattia, P., \& Gips, J. (2004). The effect of assistive technology on educational costs: Two case studies. In K. Miesenberger, J. Klaus, W. Zagler, \& D. Burger, Computers Helping People with Special Needs (pp. 206-213). Springer.

Hanson-Smith, E. (1997). Technology in the classroom: Practice and promise in the 21st century. Alexandria, VA= TESOL.

Houtz, L. E. \& Gupta, U. G. (2001). Nebraska high school students' computer skills and attitudes. Journal of Research on Computing in Education, 33, 316-325.

Hu, L. \& Bentler, P. M. (1999) Cutoff criteria for fit indexes in covariance structure analysis: Conventional criteria versus new alternatives. Structural Equation Modeling: A Multidisciplinary Journal, 6 (1), 1-55, DOI= 10.1080/10705519909540118

Jahromi, S. A., \& Salimi, F. (2013). Exploring the human element of computer-assisted language learning: an Iranian context. Computer Assisted Language Learning, 26(2), 158-176. Doi:10.1080/09588221.2011.643411

Joreskog, K. G. \& Sorbom, D. (1982). Recent Developments in Structural Equation Modeling. Journal of Marketing Research XIX, 404-16.

Kung, S.-C. (2002). A framework for successful key-pal programs in language learning. CALL-EJ Online, 3(2).

Lai, C.-C., \& Kritsonis, W. A. (2006). The advantages and disadvantages of computer technology in second language acquisition. National Journal for Publishing and Mentoring Doctoral Student Research, 3(1).

Lee, K.-w. (2000). English teachers' barriers to the use of computer assisted. The Internet TESL Journal, 6(12).

Levine, T. \& Donitsa-Schmidt, S. (1998). Computer use, confidence, attitudes, and knowledge: a casual analysis. Computers in Human Behavior, 14 (1), 125-146.

Liaw, S.-S., Huang, H.-M., \& Chen, G.-D. (2007). Surveying instructor and learner attitudes toward e-learning. Computers \& Education, 49(4), 1066-1080. Doi:10.1016/j.compedu.2006.01.001

Merisuo-Storm, T. (2007). Pupils' attitudes towards foreign-language learning and the development of literacy skills in bilingual education. Teaching and Teacher Education, 23(2), 226-235. Doi:10.1016/j.tate.2006.04.024

Mutlu, A., \& Eroz-Tuga, B. (2013). The role of computer-assisted language learning (CALL) in promoting learner autonomy. Eurasian Journal of Educational Research, 51, 107-122. 
Onsoy, S. (2004). Students' and teachers' attitudes towards the use of computer-assisted language learning at the preperatory school of Celal Bayar University. Ankara: Bilkent University.

$\mathrm{Oz}, \mathrm{H}$. (2015). Investigating the relationship between foreign language learning and call attitudes among EFL freshman students. Procedia - Social and Behavioral Sciences, 176, 1041-1049. doi=10.1016/j.sbspro.2015.01.576

Saykili, A., \& Genc Kumtepe, E. (2014). Facebook's hidden potential= Facebook as an educational support tool in foreign language education. In G. Mallia, The Social Classroom: Integrating Social Network Use in Education (pp. 120-146). Hershey PA: IGI Global.

Smith, T. D. \& McMillan, B. F. (2001). Primer of Model Fit Indices in Structural Equation Modeling. Paper presented at the Annual Meeting of the Southwest Educational Research Association (New Orleans, LA, the USA).

Teo, T. (2006). Attitudes towards computers: a study of post-secondary students in Singapore. Interactive Learning Environments, $14(1)$, 17-24.

Thomas, M., Reinders, H., \& Warschauer, M. (2013). The role of digital media and incremental change. In M. Thomas, H. Reinders, \& M. Warschauer, Contemporary Computer-Assisted Language Learning (pp. 1-11). London: Bloomsbury Academic.

Tschirner, E. (2001). Language Acquisition in the Classroom: The Role of Digital Video. Computer Assisted Language Learning, 14(3-4), 305-319. Doi:10.1076/call.14.3.305.5796

Tuncok, B. (2010). A case study: Students' attitudes towards computer assisted learning, computer assisted language learning and foreign language learning. Ankara: Middle East Technical University.

Ushida, E. (2005). The role of students' attitudes and motivation in second language learning in online courses. CALICO Journal, 23(1), 49-78.

Vandewaetere, M., \& Desmet, P. (2009). Introducing psychometrical validation of questionnaires in CALL research: the case of measuring attitude towards CALL. Computer Assisted Language Learning, 22(4), 349-380.

Wang, S., \& Heffernan, N. (2010). Ethical issues in Computer-Assisted Language Learning: perceptions of teachers and learners. British Journal of Educational Technology, 41(5), 796-813. Doi:10.1111/j.1467-8535.2009.00983.x

Warschauer, M. (1996). Comparing face-to-face and electronic discussion in the second language classroom. CALICO Journal, 13(2), 7-26.

Warschauer, M. (2004). Technological change and the future of CALL. In S. Fotos, \& C. Brown, New Perspectives on CALL for Second and Foreign Language Classrooms (pp. 15-25). Mahwah, NJ: Lawrence Erlbaum Associates.

Wu, L. X. (2010). Using CALL to improve the confidence of foreign language learners. Language \& Literacy Graduate Student Conference 2010 (pp. 1-9). Victoria: University of Victoria.

Yuan, R. (2006). A probe into learning approaches and attitudes towards technologyenhanced language learning (TELL) in Chinese instruction. Dissertation Abstracts International, Section A = The Humanities and Social Sciences, 66(10), 35603560. 